\title{
INTERNATIONAL COLLABORATION ON $\mathrm{CO}_{2}$ SEQUESTRATION
}

\author{
Annual Report \\ Reporting Period: August 23, 2001 - August 23, 2002 \\ Principal Authors: \\ Howard J. Herzog and E. Eric Adams
}

Issue date: April 2003

DOE Award No. DE-FG26-98FT40334

Massachusetts Institute of Technology

Energy Laboratory

77 Massachusetts Avenue

Room E40-455

Cambridge, MA 02139-4307

Telephone: $\quad$ (617) 253-0688

Fax: $\quad$ (617) 253-8013 


\section{Disclaimer}

This report was prepared as an account of work sponsored by an agency of the United States Government. Neither the United States Government nor any agency thereof, nor any of their employees, makes any warranty, express or implied, or assumes any legal liability or responsibility for the accuracy, completeness, or usefulness of any information, apparatus, product, or process disclosed, or represents that its use would not infringe privately owned rights. Reference herein to any specific commercial product, process, or service by trade name, trademark, manufacturer, or otherwise does not necessarily constitute or imply its endorsement, recommendation, or favoring by the United States Government or any agency thereof. The views and opinions of authors expressed herein do not necessarily state or reflect those of the United States Government or any agency thereof. 


\section{Abstract}

The main goal of our work during this time period (August 23, 2001 - August 23, 2002) was to conduct a field experiment in Norwegian waters. Preparation for the field experiment included building the apparatus, designing and obtaining the measurement systems, planning the logistics (ships, crew, supplies, etc.) and conducting a survey cruise. The survey cruise, conducted in July 2002, is documented in this report. The field experiment, scheduled for August 2002, was postponed when the Norwegian environmental minister revoked our permit under pressure from Greenpeace. Events surrounding the permitting situation are documented in the Appendix. 


\section{Table of Contents}

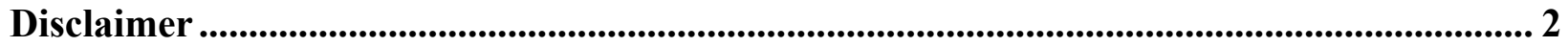

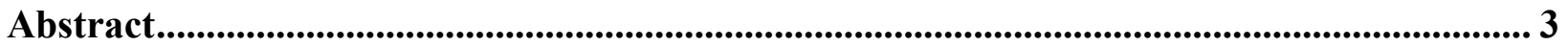

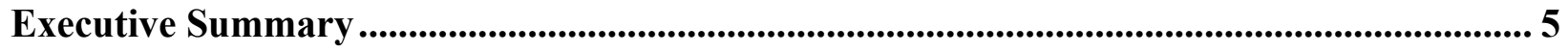

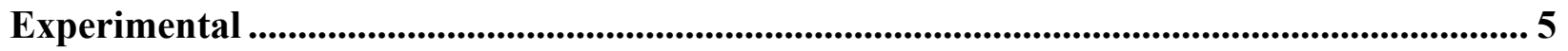

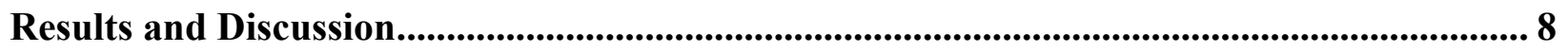

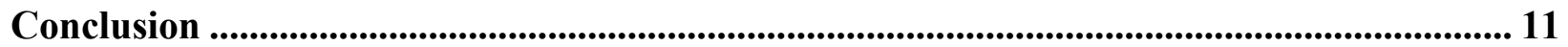

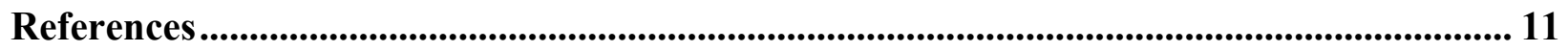

Appendix A:

Summary of the International Collaboration Project on $\mathrm{CO}_{2}$ Ocean Sequestration's Experience in Norway ............................................................................................................. 12 


\section{Executive Summary}

After studying several contingency sites, it was decided to move the experiment from Hawaii to Norway in October 2001. The primary reason for the move was the difficulty in obtaining a permit in Hawaii within the project's timeframe. In January 2002, a permit was issued for Norway and a technical planning meeting was held. A survey cruise was conducted in July 2002 and a specific site chosen for the experiment. Work was on schedule to conduct the experiment in August when the Norwegian environmental minister cancelled the permit under pressure from Greenpeace. As a result the experiment never took place.

During this period, key events included:

- Management meeting to finalize plans to move field test to Norway, January 22-23, 2002.

- $\quad$ Survey cruise, July 19-26, 1002.

- Completion of MS Thesis by Eric Wannamaker in June, 2002 entitled "Modeling Carbon Dioxide Hydrate Particle Releases in the Deep Ocean."

- Paper published: Socolofsky, S.A. and E.E. Adams, "Multi-phase plumes in uniform and stratified crossflow," Journal of Hydraulic Research, vol. 40, no. 6, (2002).

- Paper presented at the 2001 International Symposium on Environmental Hydraulics, ISEH and AIHR, (December 2001): Socolofsky S.A. and E.E. Adams, "Detrainment Fluxes for Multi-Phase Quiescent Stratification."

- Paper presented at the 2001 International Symposium on Environmental Hydraulics, ISEH and AIHR, (December 2001): Wannamaker, E.J., B.C. Crounse, S.A. Socolofsky and E.E. Adams, "Detrainment Algorithm for an integral plume model of a multi-phase plume in quiescent stratification."

This main body of this report describes the July 2002 cruise. The appendix deals with the permitting situation in Norway and the events surrounding the revoking of the permit.

\section{Experimental}

This section describes the survey cruise of July 19-26, 2002. results of the cruise are given in the following section.

The area of interest is located around 60 nautical miles north-west of Kristiansund in midNorway (Fig 1). The area forms part of the shelf break between the continental shelf and the 4,000 m deep Norwegian Sea. 


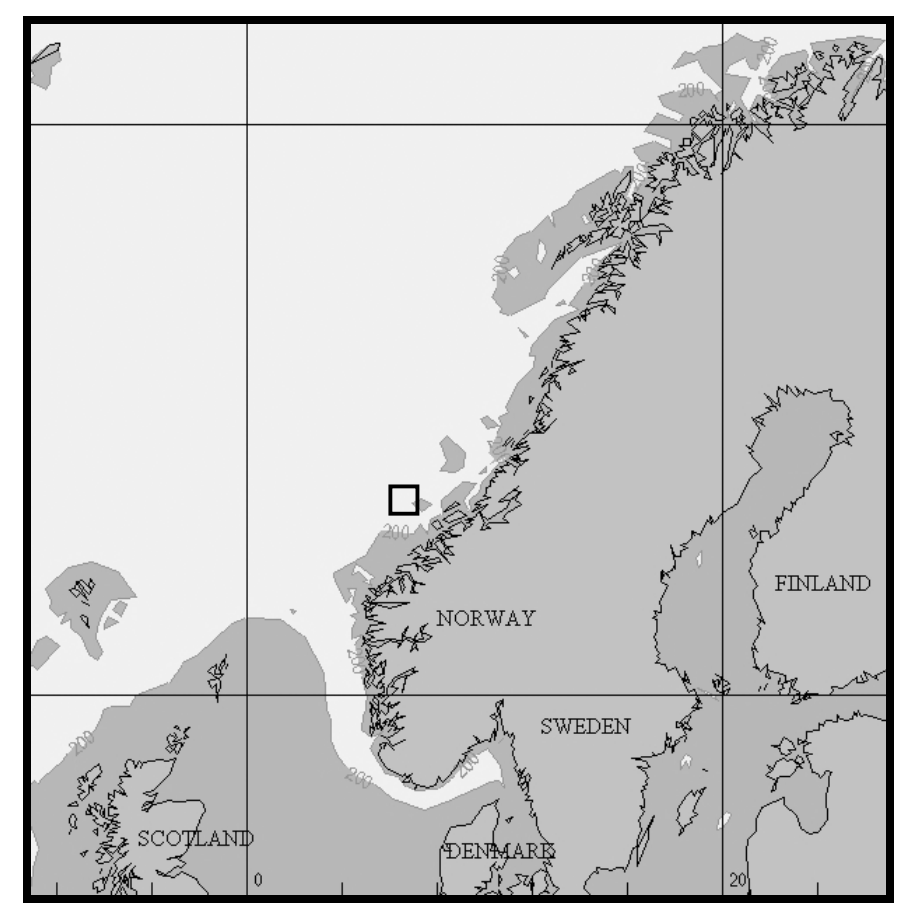

Figure 1: Map of Scandinavia and the approximate location of the site (box).

The survey area (Fig. 2) is characterised by a relatively gentle slope, typically much less than 5\% with bathymetric undulations (local ridges, mounds) with height up to a few tens of meters. The bottom mostly consists of soft sediments of biogenic origin with scattered rocks transported to the site during the last ice age.

The upper water masses are dominated by the northbound Norwegian Atlantic Current with some seasonal influence of the outer branch of the Norwegian Coastal Current which tends to split in two branches at about 6330'N (Satere, 1999). Surface salinities around 32 and temperatures up to $15^{\circ} \mathrm{C}$ were measured during the 2002 survey. From ca $100 \mathrm{~m}$ and down to $400 \mathrm{~m}$ warm and salty Atlantic Water with temperature typically between 6 and $9^{\circ} \mathrm{C}$ and salinity up to 35.2 was found. A pronounced thermocline and a less pronounced halocline between 350 and $600 \mathrm{~m}$ mark the transition to the colder Arctic Intermediate water, with temperatures of $<0.5$ ${ }^{\circ} \mathrm{C}$ and salinity of about 34.8-34.9.

The survey was performed from the $50 \mathrm{~m}$ long, $700 \mathrm{t} \mathrm{R} / \mathrm{V}$ "Håkon Mosby" with 13 participants from 3 countries and 8 scientific institutions (see Table 1). Loading and unloading of the vessel took place in its home port, Bergen. The vessel sailed from port right after midnight, on July 21. Steaming to the site took about 22 hours and a acoustic bottom survey and water sampling began once the site was reached. The survey consisted of many related activities, including echo sounder transects, ROV dives, CTD profiles, carbon chemistry analysis, ${ }^{13} \mathrm{C} /$ bacterial production rates, sediment grab samples, scavenger trap deployments, long line fishing, fish trap deployments, trawling, zooplankton net hauls, and ADCP current measurements. 


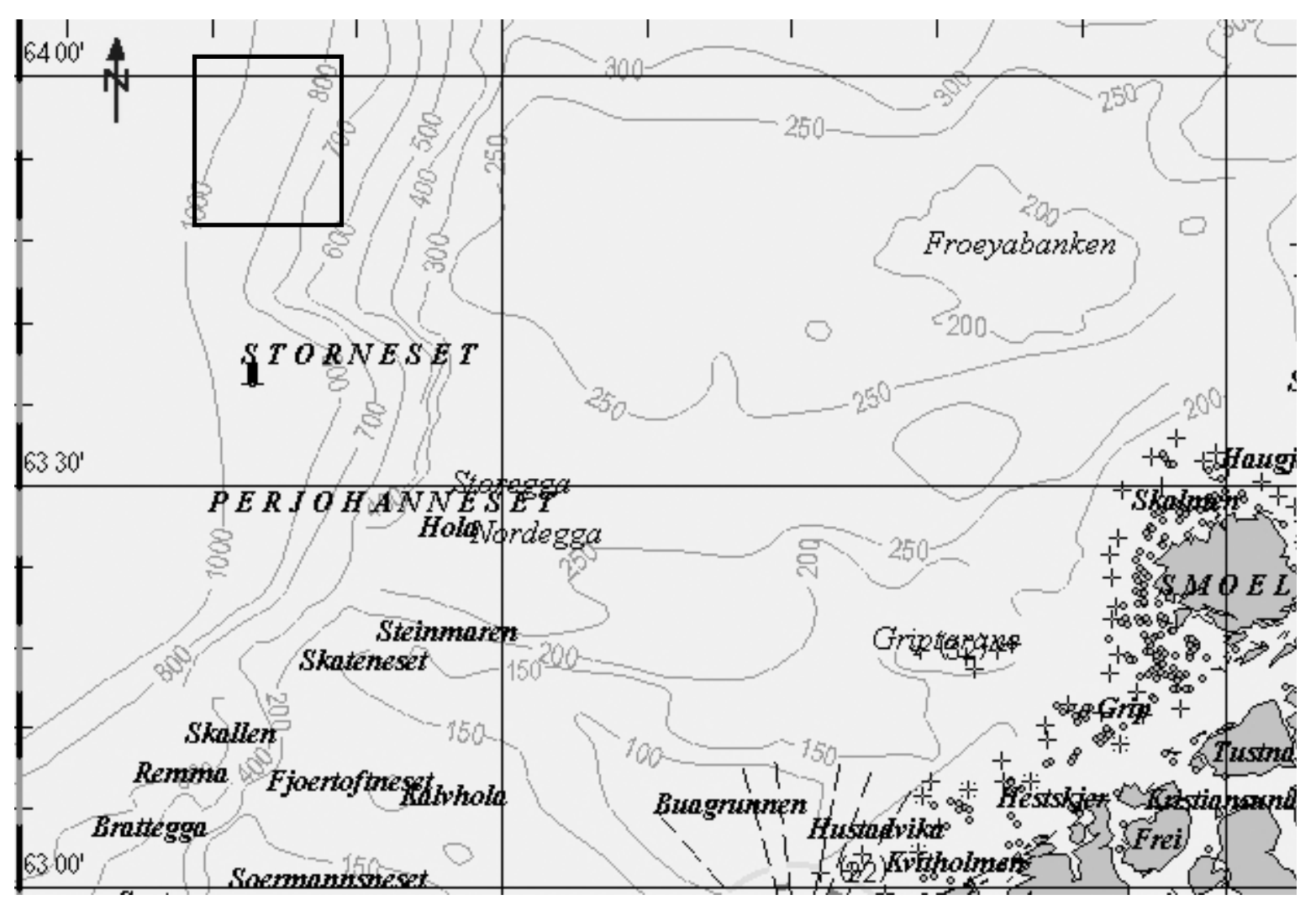

Figure 2: Extract from Nautical map \# 558 with the area NW of Kristiansund. The survey area (indicated by box) was around the $800 \mathrm{~m}$ isobath near $63^{\circ} 50^{\prime} \mathrm{N}$.

Table 1

SURVEY PARTICIPANTS AND THEIR RESPECTIVE MAIN RESPONSIBILITIES.

\begin{tabular}{|c|c|c|c|}
\hline \multicolumn{4}{|c|}{ Survey participants } \\
\hline Country & Institution & Name & Primary activity \\
\hline \multirow[t]{2}{*}{ Canada } & \multirow[t]{2}{*}{ Institute of Ocean Sciences (IOS) } & Melissa Chierici & \multirow{2}{*}{$\begin{array}{l}\text { Seawater carbon } \\
\text { chemistry }\end{array}$} \\
\hline & & Agneta Fransson & \\
\hline \multirow[t]{6}{*}{ Norway } & \multirow{2}{*}{$\begin{array}{l}\text { Norwegian Institute for Water } \\
\text { Research (NIVA) }\end{array}$} & Arild Sundfjord & Chief scientist, ADCP \\
\hline & & Nils R. Hareide & Deepwater fishing \\
\hline & Inst. of Marine Research (IMR) & M. Johannessen & Pelagic biology \\
\hline & \multirow{3}{*}{ University of Bergen (UoB) } & Reidun Gangstø & CTD, sampling \\
\hline & & Vidar Saue & \multirow[t]{2}{*}{ ROV operations } \\
\hline & & Trond Jensen & \\
\hline \multirow[t]{5}{*}{ USA } & $\begin{array}{l}\text { Massachusetts Inst. of } \\
\text { Technology (MIT) }\end{array}$ & Scott Socolofsky & Bathymetry, CTD \\
\hline & University of Hawai'i (UH) & Craig Smith & Benthic biology \\
\hline & Hawai’i Pacific University (HPU) & Eric Vetter & Sediments, biology \\
\hline & \multirow[t]{2}{*}{ Naval Reseach Laboratory (NRL) } & Keri Beeson & \multirow[t]{2}{*}{ Bacterial production } \\
\hline & & Rick Coffin & \\
\hline
\end{tabular}




\section{Results and Discussion}

The following criteria were used for the site selection: 1) As flat a region as possible, 2) As homogeneous surroundings as possible, 3) Avoid region near underwater landslide

"Storeggaraset" to the South, 4) Prefer regions in water little less than $800 \mathrm{~m}$ to depths greater than $800 \mathrm{~m}$ and 5) Suitably stable sediments and richness in biology.

Based on bathymetric and other data, three potential sites with the desired characteristics were first identified, and the southernmost of these, centred at $63^{\circ} 50^{\prime} \mathrm{N}, 05^{\circ} 20^{\prime} \mathrm{E}$, was ultimately identified as the most suitable after more thorough investigation of the bottom. This area of $\sim 500$ $\mathrm{m} \times 500 \mathrm{~m}$ extent has a very mild slope, and only in the south-east to north-west direction. Some ridge-like features with max height of 10-20 m were captured by the echo-sounder and confirmed by ROV observations. The upper layer of the sediments were of biogenic origin with a 3-4 cm fluffy layer on top and fine-grained grey clay deeper down, with streaks of black inbetween.

To measure currents, an RDI $75 \mathrm{kHz}$ Long Ranger ADCP was deployed at $809 \mathrm{~m}$ depth for a period of almost 4 days near the western boundary of the recommended site. The logging interval was 10 minutes and the cell thickness $5 \mathrm{~m}$, allowing a $500 \mathrm{~m}$ vertical range. Statistical values for given depths are shown in Table 2 and plots of current velocity and direction at $775 \mathrm{~m}$ depth in Fig. 3.

TABLE 2

STATISTICAL VALUES FOR CURRENT VELOCITY (CM/S) AND DIRECTION (DEG) FOR GIVEN DEPTHS

\begin{tabular}{|l|l|l|l|l|l|l|l|l|l|l|l|}
\hline Depth [m] & $\mathbf{7 9 0}$ & $\mathbf{7 7 5}$ & $\mathbf{7 5 0}$ & $\mathbf{7 2 5}$ & $\mathbf{7 0 0}$ & $\mathbf{6 5 0}$ & $\mathbf{6 0 0}$ & $\mathbf{5 5 0}$ & $\mathbf{5 0 0}$ & $\mathbf{4 0 0}$ & $\mathbf{3 0 0}$ \\
\hline Average velocity & 7.3 & 7.0 & 7.2 & 7.1 & 6.8 & 6.6 & 6.2 & 7.2 & 7.9 & 16.7 & 25.8 \\
\hline Minimum velocity & 0.2 & 0.4 & 0.3 & 0.4 & 0.3 & 0.3 & 0.1 & 0.1 & 0.1 & 3.3 & 3.7 \\
\hline Maximum velocity & 18.5 & 18.6 & 21.3 & 16.2 & 18.2 & 16.3 & 16.2 & 18.7 & 25.1 & 32.3 & 40.2 \\
\hline RMS Velocity & 2.0 & 2.0 & 2.1 & 1.7 & 1.1 & 1.2 & 0.8 & 1.4 & 3.8 & 14.9 & 24.1 \\
\hline RMS Direction & 192 & 201 & 190 & 204 & 223 & 208 & 177 & 11 & 358 & 356 & 358 \\
\hline
\end{tabular}

CTD measurements were made at five positions. A central station with bottom depth $813 \mathrm{~m}$ was profiled seven times, with water samples for different analyses being taken at various depths. Since the $\mathrm{CO}_{2}$ experiment would affect deeper water masses only, CTD plots of the 700-800 m depth interval are presented in Fig. 4. Near-bottom salinities were around 34.91, and temperatures were between -0.8 and $-0.9{ }^{\circ} \mathrm{C}$. The corresponding seawater density was around 28.075 in $\operatorname{sigma}_{\theta}$. Data on seawater chemistry will be reported in the final report [7].

The vertical distribution of the fish species in the continental slope Storegga (see Fig. 5) is determined by sea temperature. Only species that can live in temperatures lower than $2{ }^{\circ} \mathrm{C}$, such as Greenland halibut (Reinhardtius hippoglossoides), rough head grenadier (Macrourus berglax), Arctic skate (Raja hyperborea) and some species of eelpouts (Zoridae spp.) are present at depths greater than $650 \mathrm{~m}$. Greenland halibut, rough head grenadier and Arctic skate highest density between 550 and 670 meters at temperatures between 3 and $0^{\circ} \mathrm{C}$. The eelpouts live in temperatures between 0,5 and $-1,5^{\circ} \mathrm{C}$ and hence deeper than $650 \mathrm{~m}$. The majority of species presented in Figure 5 spawn at Storegga. The main spawning period is mid winter. It is not 
expected that the Greenland halibut spawns deeper than about 670 meters. The most important commercially exploited species at the continental slope are ling, tusk and blue ling. Fishing for these species is conducted from the shelf break down to 550 meters, i.e. shallower than the proposed experiment depth.

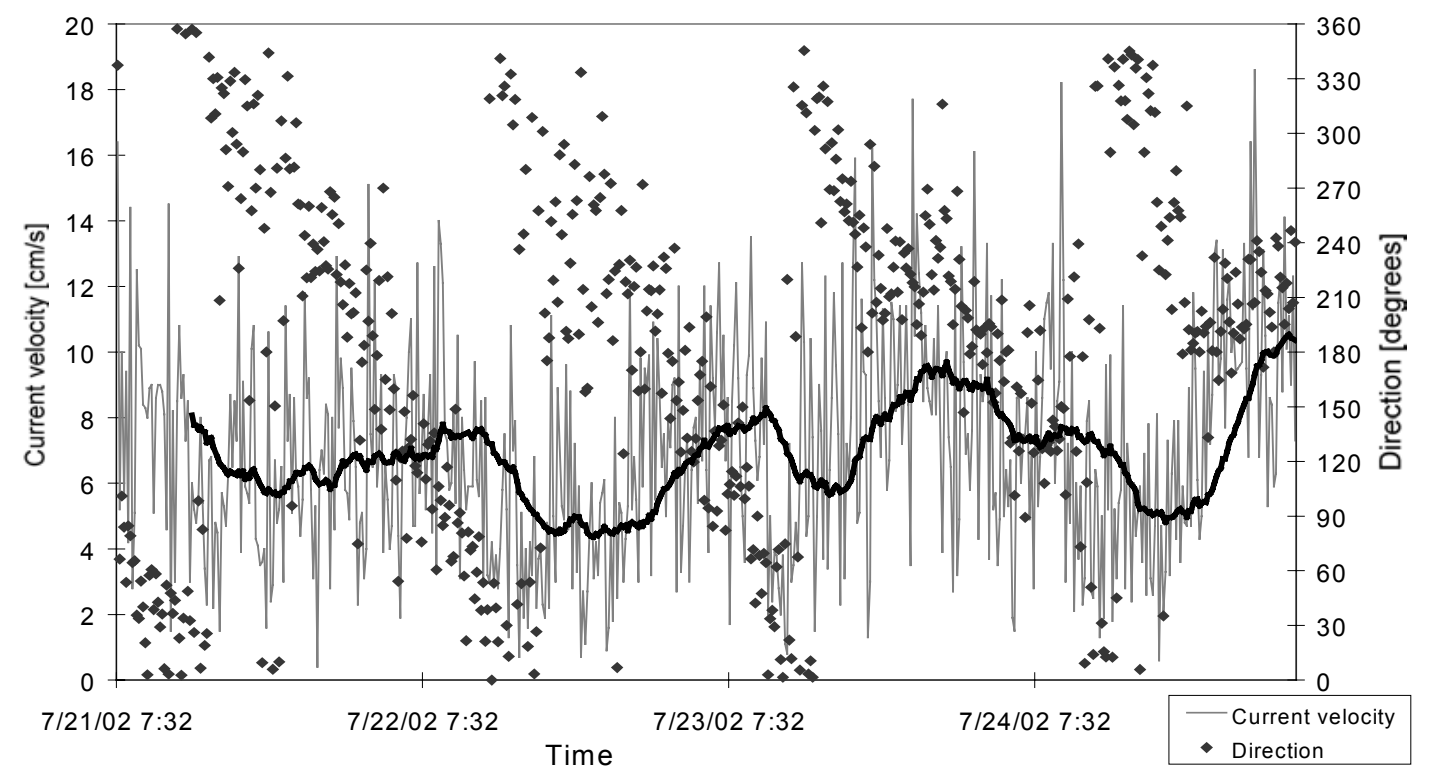

Figure 3: Measured current velocity (thin line; $\mathrm{cm} / \mathrm{s}$ ) and current direction (dots; degrees) at 775 $\mathrm{m}$ depth. A 6-hr moving average for speed is shown by the smooth line. 

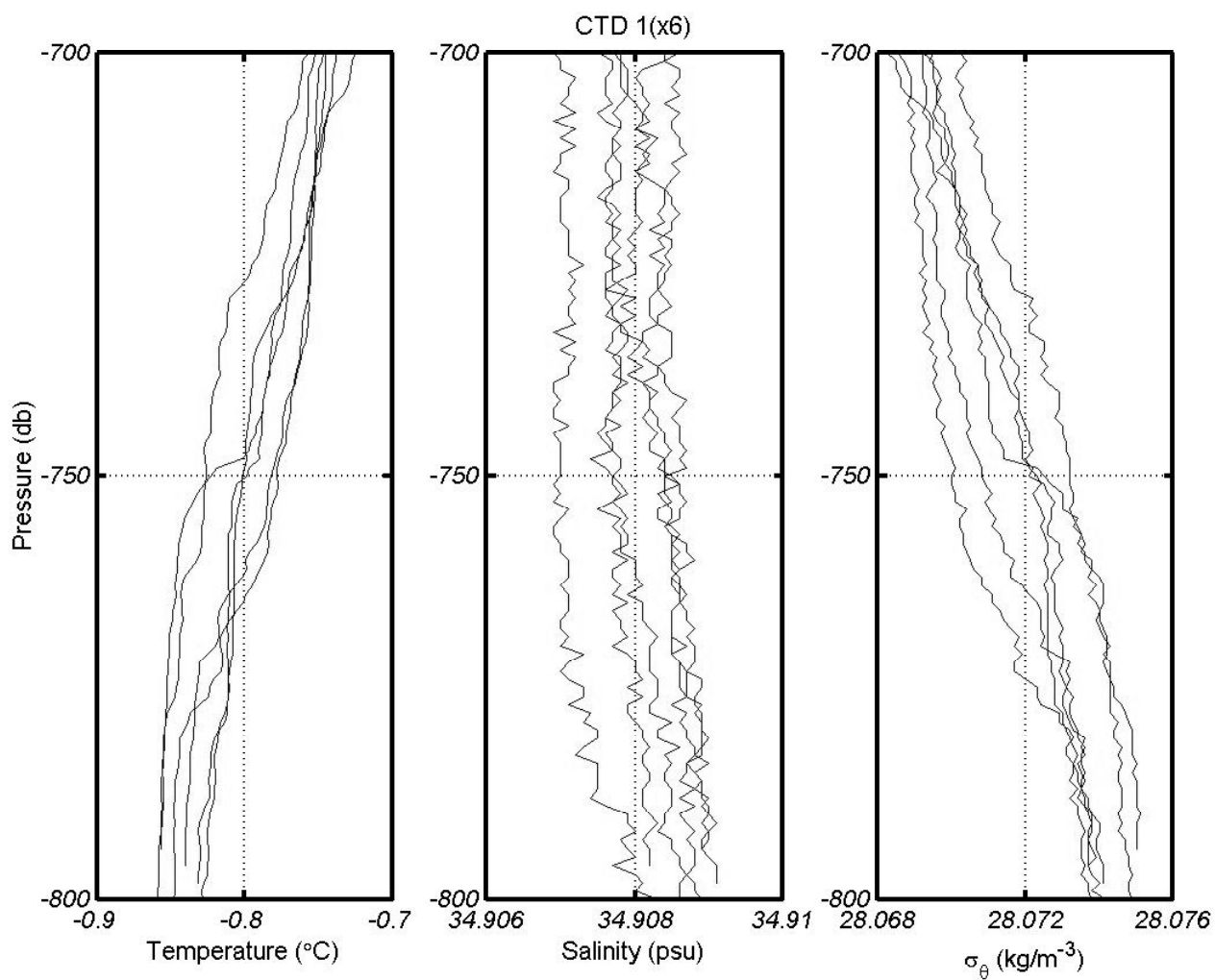

Figure 4: Temperature, salinity and density vs. pressure in the 700-800 dbar (m) interval from 6 CTD profiles taken at the site during 21-24 July, 2002.

Scavenger traps deployed during the survey were successful in collecting large numbers of brightly coloured amphipods over a period of a few hours, which indicates that the use of traps to collect and observe organisms would be successful during the $\mathrm{CO}_{2}$ experiment. The bottom biology was rich, and representative of what would be expected at these depths and temperatures. 


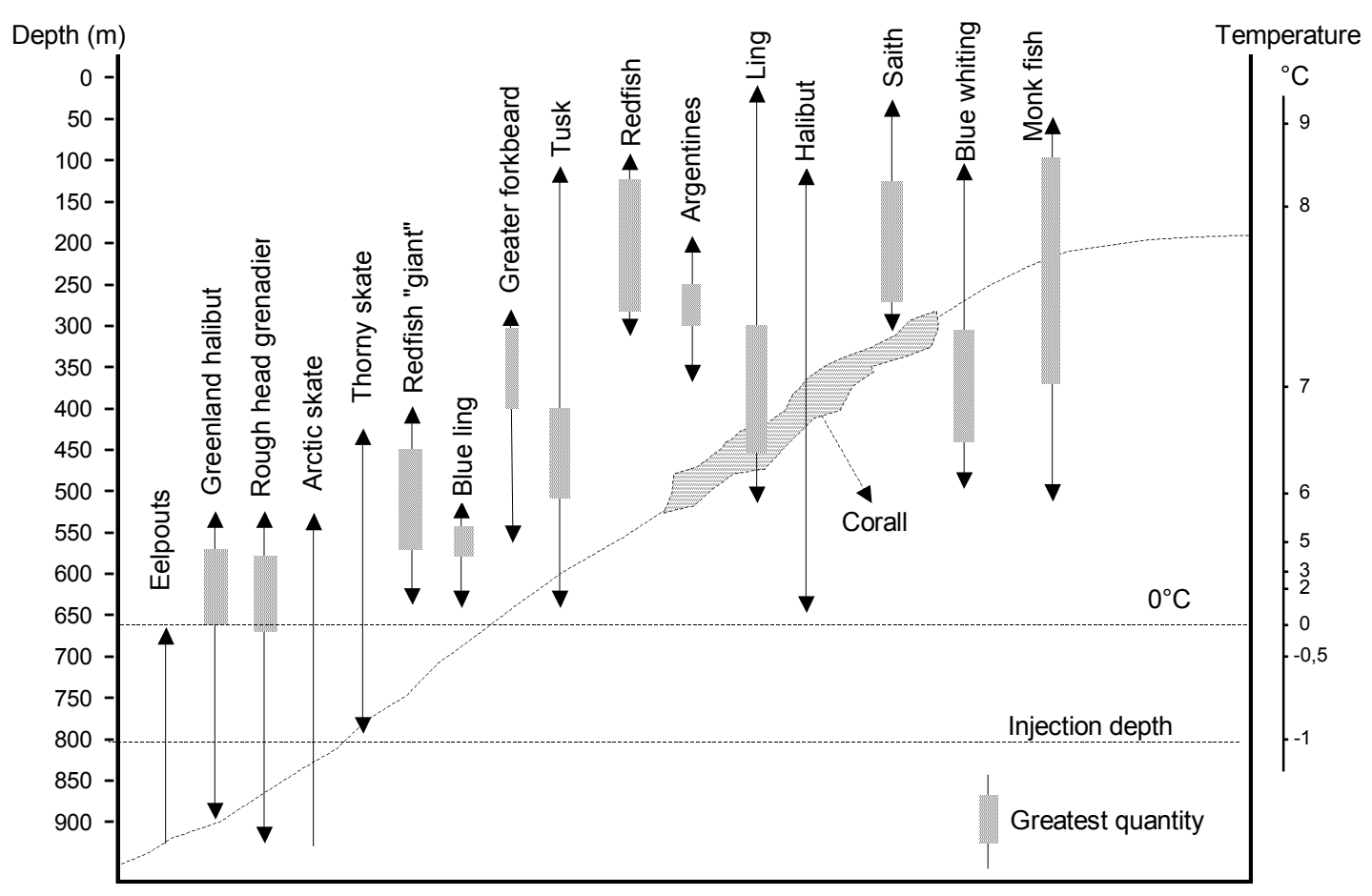

Figure 5: Vertical fish species distribution in the area of investigation based on existing data.

\section{Conclusion}

The survey cruise identified an excellent site for the experiment. The experimental equipment was all set to go. The measurement procedures were all in place and the instruments ready to be deployed. Unfortunately, as described in the Appendix, the field experiment had to be postponed due to the last minute revocation of the permit.

\section{References}

Saetre, R., Features of the Norwegian shelf circulation, Continental Shelf Research, 19, p 18091831 (1999). 


\title{
Appendix A:
}

\section{SUMmaRY OF THE INTERNATIONAL COLlaboration Project ON $\mathrm{CO}_{2}$ OCEAN SEQUESTRATION'S EXPERIENCE IN NORWAY}

\begin{abstract}
An international research consortium was formed in 1997 to observe the behavior of $\mathrm{CO}_{2}$ when released into the deep ocean. The Kona coast of Hawaii was selected as the project site. A local opposition group forced unacceptably long permitting delays that ultimately forced the project to move out of Hawaii. The consortium selected Norway as the new site. A permit was easily acquired from the national pollution authority in January 2002. A member of Norway's opposition party raised concerns about the experiment in Parliament. The Ministry of Environment responded by reopening the permitting process and requiring public hearings during June. The pollution authority reissued the permit in July ruling the opposition's arguments were not compelling. The Minister of Environment, Børge Brende, revoked the permit in a surprise ruling on August $22^{\text {nd }} 2002$.
\end{abstract}

\section{Introduction}

Background (project goals and history)

In 1997 an international project agreement was signed in Kyoto, Japan to study the direct injection of $\mathrm{CO}_{2}$ into the ocean. Injecting $\mathrm{CO}_{2}$ captured from anthropogenic sources into the ocean is one potential future strategy to help stabilize atmospheric concentrations of $\mathrm{CO}_{2}$. Before policy makers can decide if ocean sequestration should be employed, several areas of scientific uncertainty must be addressed. This project set out to clarify some of these issues. One goal was to analyze various $\mathrm{CO}_{2}$ discharge scenarios to maximize sequestration potential and minimize environmental impact. A second goal was to obtain data sets to validate plume behavior models. Finally, the experiment was to determine the effect, if any, on deep-sea biological organisms.

\section{Hawaii; what went wrong}

The project's Steering Committee (SC) originally selected a site off the Kona coast of Hawaii. The Kona coast was selected because it met all required experimental conditions, had sufficient infrastructure, and most importantly was located in an "ocean research corridor" operated by The Natural Energy Laboratory of Hawaii Authority (NELHA), a project collaborator. The SC was led to believe that being located in the research corridor would make for a quick and easy permitting process.

Fierce opposition to the experiment was mobilized by a small but vocal campaign called the Coalition Against $\mathrm{CO}_{2}$ Dumping. ${ }^{1,2}$ The experiment was also delayed by objections from the US EPA. A fixed time schedule required the project to be completed by the end of 2002. It was assessed that the opposition could delay permitting beyond that time. Even if the permit was

\footnotetext{
${ }^{1}$ www.kahea.org/co2

2 de Figueiredo, M. et al. "Ocean Carbon Sequestration: A Case Study in Public and Institutional Perceptions," Sixth International Conference on Greenhouse Gas Control Technologies, Kyoto, Japan, October 1-4, (2002).
} 
received in time, a lawsuit seemed likely. In order to get the project done on time the SC began to search for alternate sites.

\section{Alternate Site selection}

The SC held an ad-hoc meeting in London in August 2001 to discus alternate locations to do the experiment. The short-list consisted of Norway, Bermuda, and the Gulf Coast of the US. Each site had positive and negative aspects. The SC decided to scale down the experiment from injecting 50 tons of $\mathrm{CO}_{2}$ (as planned in Kona) to 5 tons.

\section{Gulf Coast}

The Gulf Coast is subject to EPA regulation. The project was already running into permitting problems with EPA in Hawaii and was uncertain how receptive EPA would be with this choice. The Gulf Coast was not considered as a serious option.

\section{Bermuda}

Permitting was thought to be straightforward in Bermuda. BBSR, a prominent US research institute, is located there and was interested in collaborating and facilitating the permitting process. To avoid EPA jurisdiction ships and $\mathrm{CO}_{2}$ sources would have had to been procured outside the US - causing logistical problems. It would take two years to procure the ship and necessary infrastructure. Because of this Bermuda was rejected as a back-up site in December.

\section{Norway}

Norway is a member country of the consortium. Project-specific knowledge and infrastructure could be found locally because a similar experiment had been conducted in 2000 by the foundation for Scientific and Industrial Research at the Norwegian Institute of Technology (SINTEF). SINTEF - one of the biggest research groups in Scandinavia -

had studied a deep-sea oil release and was interested in following up that work by collaborating on the $\mathrm{CO}_{2}$ experiment. SINTEF provided the $\mathrm{CO}_{2}$ experiment team with technical and permitting advice.

Carbon sequestration was on Norway's political agenda because of Statoil's Sleipner offshore $\mathrm{CO}_{2}$ storage project - the first effort of its kind. There is also a proposal to require new naturalgas plants to sequester $\mathrm{CO}_{2}{ }^{3}$

One drawback was that Norway offered a narrow weather window in which to do the project. The experiment could only be done between May and September.

\section{Project happenings}

In October 2001 the SC selected Norway as an alternative site. The southeastern rim of the Norwegian Sea Basin (100-200 km off the coast of Trondheim) was picked as a feasible location. The Norwegian Institute for Water Research (NIVA), the Norwegian member of the consortium, met with the Norwegian Pollution Control Authority (SFT) in November 2001 to discus permitting. NIVA was reassured that it should be a smooth process.

\footnotetext{
${ }^{3}$ Quiviger, G., "Building New Power Plants in a CO2 Constrained World: A Case Study from Norway on Gas-Fired Power Plants, Carbon Sequestration, and Politics, " M.I.T. Masters Thesis, (2001).
} 
NIVA was chosen as the lead organization to apply for the permit. They had been intimately involved with the experiment from the beginning and had contacts in both the SFT and Ministry of Environment.

\section{Permitting process}

A NIVA representative met with SFT officials on December $19^{\text {th }} 2002$ to officially begin the permitting process. The meeting was generally positive and an application for the permit was submitted on January $18^{\text {th }}, 2002 .{ }^{4}$ SFT issued a permit for the experiment on January $24^{\text {th }}$. It stated that the project was not required to prepare an environmental assessment nor did it have to hold public meetings due to its low and innocuous discharge levels.

In February the SC tentatively scheduled the experiment for July $19^{\text {th }}$ through August $2^{\text {nd }}, 2002$. Preparations were started to contract ships and procure the required infrastructure.

\section{Project Opposition}

$\mathrm{NGO}$ rational for opposing $\mathrm{CO}_{2}$ sequestration

Greenpeace has long been opposed to the idea of $\mathrm{CO}_{2}$ ocean sequestration based on several main points. They claim it ${ }^{5}$ :

distracts attention/resources from the development of renewable energy sources, will leak $\mathrm{CO}_{2}$ back to the atmosphere, harms the marine ecosystem, is illegal under international treaties. ${ }^{6}$

Arguments along these same lines are made by other environmental pressure groups opposed to ocean sequestration, such as the World Wildlife Federation (WWF). It should be noted that the proposed experiment was too small-scale to cause any environmental harm. While the NGO's acknowledged this point, they still expressed concern that the experiment was a "proof-ofconcept" and would lead to full-scale commercial applications of sequestration technologies.

\section{Political and institutional challenges}

Project members began to receive press inquiries about the move to Norway in late May. It's unknown when and how information of the move was leaked. Many articles were written about the project in the Norwegian press.

Greenpeace claimed that the experiment was in violation of the OSPAR Convention. OSPAR is a treaty that regulates ocean dumping in the northeast Atlantic Ocean. ${ }^{7}$ To dump an industrial waste under OSPAR, it must fall under one of five exempted categories or be on a positive list. $\mathrm{CO}_{2}$ fits neither requirement. The issue of $\mathrm{CO}_{2}$ sequestration under OSPAR is under debate and

\footnotetext{
${ }^{4}$ Permit application in Annex 1

${ }^{5}$ www.greenpeace.to/pdfs/co2dump.pdf

${ }^{6}$ Relevant treaties include the OSPAR Convention and the London Dumping Convention. For a more subtle treatment of this issue, see Heinrich, J. "Legal Issues of CO2 Ocean Storage", working paper MIT's Lab for Energy and Environment, (2002).

${ }^{7}$ Www.ospar.org
} 
is on the agenda for OSPAR's June 2003 meeting. Greenpeace submitted a formal statement at the June 2002 meeting denouncing the experiment as illegal and requesting Norway to refuse the permit. $^{8}$

During the first week of June, a member of Norway's opposition party - prompted by Greenpeace - raised the issue of the experiment in Parliament. As a result, the Minister of Environment, Børge Brende, instructed SFT to conduct public hearings. The hearings ran from June $11^{\text {th }}$ to $27^{\text {th }}$. Greenpeace Nordic, WWF Norway and the Norwegian Nature Conservation Society filed complaints inline with the objections mentioned above. Various other NGOs and fisherman-groups were neutral or supportive of the project. SFT reissued the permit on July $5^{\text {th }}$ after finding no compelling argument by the opposition. After the reissuing, organizations had three weeks to appeal the ruling. All appeals went directly to the ministry. Only WWF and Greenpeace appealed (with the same arguments as the first round).

\section{Publicity challenges}

Greepeace initiated a media campaign against the experiment. ${ }^{9}$ They sent their flagship "Rainbow Warrior" on July $17^{\text {th }}$ to protest the project. ${ }^{10}$ The ship's crew invited representatives from NIVA and the Ministry of Environment onboard for a meeting. Both NIVA and the Ministry declined, offering to meet after the Minister's ruling. But the (in)famous ship attracted significant media attention

\section{Survey Cruise}

A survey cruise took place between July $20^{\text {th }}$ and $26^{\text {th }} 2002$. It established two good locations to conduct the experiment and made some initial environmental measurements. It was considered a success.

\section{Minister revokes permit}

Signals coming from the ministry throughout August appeared to be favorable towards the project. On August $22^{\text {nd }}$, however, the Ministry of Environment issued a press release, which immediately revoked the permit issued by SFT. ${ }^{11}$ The release stated, "the use of deep marine areas as possible future storage places for $\mathrm{CO}_{2}$ should first be thoroughly discussed internationally and the legal implications clarified." It sited the uncertain status of ocean sequestration under the OSPAR convention. It also states "an international discussion of the issue is desirable and necessary, and [the Ministry] has also based its decision on the fact that the experiment will not significantly increase understanding of possibilities for future leakages of $\mathrm{CO}_{2}$ to the atmosphere."

The press release's lack of coherence underscores the political nature of the decision. The stated goals of the project were to provide an objective scientific basis for the "international discussion" the minister called for. Both the NGOs and the Minister acknowledged that the experiment would cause minimal impact on the marine ecosystem.

\footnotetext{
${ }^{8}$ Greenpeace's statement to OSPAR in Annex 2

${ }^{9}$ Press releases found in Annexes 3 and 4

${ }^{10}$ News story from Planet Ark in Annex 5

${ }^{11}$ Ministry of Environment's press release in Annex 6
} 
The decision to revoke the permit drew wide international attention. Articles appeared in the journals Nature, ${ }^{12}$ Environmental Science and Technology, ${ }^{13}$ and the general press ${ }^{14}$.

Timeline of Events related to the Experiment in Norway

\begin{tabular}{|c|c|}
\hline Date & Event \\
\hline $\begin{array}{l}\text { December 4, } \\
1997\end{array}$ & $\begin{array}{l}\text { Project Agreement for International Collaboration on } \mathrm{CO}_{2} \text { Ocean } \\
\text { Sequestration in Kyoto }\end{array}$ \\
\hline March 1, 1998 & Project Site off Kona Coast in Hawaii chosen. \\
\hline May, 2001 & $\begin{array}{l}\text { Federal government issues Finding of No Significant Impact for } \\
\text { NELHA }\end{array}$ \\
\hline August, 2001 & $\begin{array}{l}\text { SC holds ad-hoc meeting in London to discus contingency sites. } \\
\text { Bermuda and Norway are top candidates. Permitting a major } \\
\text { concern. }\end{array}$ \\
\hline October, 2001 & Norway chosen as contingency site \\
\hline November, 2001 & Introductory meetings with SFT held \\
\hline January 18,2002 & Application for permit submitted to SFT \\
\hline January 24, 2002 & $\begin{array}{l}\text { Permit is issued. No environmental assessment or public hearing is } \\
\text { required. }\end{array}$ \\
\hline $\begin{array}{l}\text { February 21, } \\
2002\end{array}$ & $\begin{array}{l}\text { Experiment tentatively scheduled for July 19th through August 2nd, } \\
2002\end{array}$ \\
\hline Late May, 2002 & Story leaks and the experiment's move to Norway is exposed. \\
\hline Early June, 2002 & $\begin{array}{l}\text { Issue of the experiment raised in Norway's Parliament. Minister } \\
\text { orders public hearings on the experiment. }\end{array}$ \\
\hline $\begin{array}{l}\text { June } 11-27 \\
2002\end{array}$ & Hearings held. \\
\hline July 4, 2002 & $\begin{array}{l}\text { SFT sends letter reissuing the permit. Gives three-week appeal } \\
\text { period. }\end{array}$ \\
\hline July 17, 2002 & "Rainbow Warrior" arrives in Norway to protest experiment. \\
\hline July $20-26,2002$ & $\begin{array}{l}\text { Survey cruise is conducted to select a good site and collect } \\
\text { background environment data }\end{array}$ \\
\hline August 22, 2002 & $\begin{array}{l}\text { Minister of Environment, Børge Brende, revokes permit citing } \\
\text { possible violation of OSPAR treaty and need for further } \\
\text { international discussion. }\end{array}$ \\
\hline
\end{tabular}

\footnotetext{
${ }^{12}$ Nature news story in Annex VII

${ }^{13}$ Environmental Science and Technology news and letter in Annexes VIII and IX

${ }^{14}$ Environmental News Service story in Annex X
} 


\section{ANNEX I}

Document description: Application to SFT (Norwegian Control Authority) for permission to carry out an experimental release of $\mathrm{CO}_{2}$ (Carbon dioxide) in deep waters in the Norwegian Sea. Submitted January $18^{\text {th }}, 2002$

\section{Summary}

On behalf of an international group of scientific organizations, NIVA, The Norwegian institute for water research, is planning an experimental release of carbon dioxide in the Norwegian Sea ( west of the Storegga) during the period 22 July-11 August (weeks 30-32), 2002. The release will be from the ocean floor at a depth of $800 \mathrm{~m}$. The experiment is motivated by the need for increased knowledge about the chemical, physical, and biological effects of releasing carbon dioxide in seawater. In the future, $\mathrm{CO} 2$ may have $\mathrm{t}$ be released and dissolved in the deep ocean in order to reduce $\mathrm{CO} 2$ build-up in the atmosphere.

\section{Applicant}

The applicant for the release is NIVA, the Norwegian institute for water research, on behalf of an international scientific group that consists of:

- $\quad$ AIST, National Institute of Advanced Industrial Science and Technology, Japan

- CRIEPI, Central Research Institute of Electric Power Industry, Japan

- CSIRO, Commonwealth Scientific and Industrial Research Organization, Australia

- HPU, Hawaii Pacific University, USA

- IOS, Institute of Ocean Sciences, Canada

- KU, Kyoto University, Japan

- MIT, Massachusetts Institute of Technology, USA

- $\quad$ NERSC, Nansen Environmental and Remote Sensing Center, Norway

- NIVA, the Norwegian institute for water research, Norway

- PICHTR, Pacific International Center for High Technology Research, USA

- RITE, Research Institute of Innovative Technology for the Earth, Japan

- UH, University of Hawaii, USA

- UoB, University of Bergen, Norway

Each organization is sponsored by governmental funding bodies in the respective countries; Department of Energy (DOE) in the USA, New Energy and Industrial Technology Development Organization (NEDO) in Japan, National Research Council (NRC) of Canada, Norwegian Research Council (NFR) in Norway, ABB Corporate Research in Switzerland and CSIRO in Australia. The agreement to plan and perform the joint experiment was formed under the IEA/OECD Climate Technology Initiative and signed at COP-3 in Kyoto in December, 1997.

\section{Time and Place for the releases}

The planned release will last one week within the 3 weeks time frame applied for. The extra time is for mobilization, demobilization and waiting time in the case of bad weather.

The release site will be located ca $75 \mathrm{n}$ miles NW of Kristiansun. The site will be located within a small area specified by the co-ordinates (see map) 
$63^{\circ} 20^{\prime}-63^{\circ} 55^{\prime} \mathrm{N}$

$05^{\circ} 10^{\prime}-05^{\circ} 40^{\prime} \mathrm{E}$

What and how much will be released

10 experimental releases are planned, each comprising no more than $750 \mathrm{~kg} \mathrm{CO}_{2}$. Each release will last for maximum 2 hours. Momentary fluxes of $\mathrm{CO}_{2}$ will be adjusted according to the limits $0.1 \mathrm{~kg} / \mathrm{s}$ (minimum) and $0.3 \mathrm{~kg} / \mathrm{s}$ (maximum). The release platform is a well-proven unit containing $20 \mathrm{CO}_{2}$ canisters that are charged with $\mathrm{CO}_{2}$ on board the supply vessel and then lowered to the seabed prior to each release. Valves that can be operated both remotely from the sea surface and mechanically by a ROV are controlling the release of the gas. There will be one or two releases per day. Each release will be accompanied and followed by careful monitoring, measurements and observations of the $\mathrm{CO}_{2}$ droplets and the plume of $\mathrm{CO}_{2}$ enriched water.

\section{Basis for the releases}

There is growing concern that increased $\mathrm{CO}_{2}$ levels in the atmosphere from burning of fossil fuels such as coal, oil and gas will cause climate change and severed damage to both property and the environment. Such damage is probably already taking place and projections of fossil fuel consumption strongly indicates that actions need to be taken very soon in order to reduce the emission to the atmosphere. Ocean sequestration of $\mathrm{CO}_{2}$ is considered a possible method to mitigate climate change, by first capturing the $\mathrm{CO}_{2}$ gas from large stationary sources such as power plants and then injecting and dissolving in the deep ocean. In this way, the captured $\mathrm{CO}_{2}$ remains away from the atmosphere for 1.000 years or more. Several steps need to be taken in order to better understand this technology, from small scale to large scale tests. The experiment as applied for, constitute pioneering work on the local scale to continuously release small amounts of $\mathrm{CO}_{2}$ into the seawater in order to study behavior of the gas before it is completely dissolved and diluted in the water.

\section{Environmental effects of the releases}

When $\mathrm{CO}_{2}$ is injected into the ocean during the experimental release, a plume of droplets and $\mathrm{CO}_{2}$ enriched water will be formed. Computer simulations show that the plume will have a maximum rising height of $100 \mathrm{~m}$ before it is dissolved and carried away from the release point by the prevailing ocean currents. Through a carefully designed observational programme the physical behavior of the droplets and the plume will be recorded and analyzed. Some change in the seawater chemistry such as lowered $\mathrm{pH}$ as the seawater becomes acidic is expected to take place near the release point. Laboratory studies have provided limits of tolerance of various seawater species versus $\mathrm{pH}$. Computer simulations for the experimental releases we plan in this experiment show that there will be no significant biological impacts. However, exposure to low $\mathrm{pH}$ for an extended time period may affect animals in the vicinity of the plume and it is also an objective of the experiment to observe and learn about such effects.

\section{Accessibility and dissemination of results}

Results will be shared among the partners to the international project. Data will be published in international peer-reviewed journals. Computer models will be improved in order to be able to provide better projections on the efficiency and impacts from future large scale $\mathrm{CO}_{2}$ ocean sequestration. The final evaluations of results from the experiment will help to document whether $\mathrm{CO}_{2}$ ocean sequestration may become a viable future climate technology both in terms of environmental impact and technological feasibility.

Source: internal documents of MIT's Lab for Energy and Environment 


\begin{abstract}
ANNEX II
Document description: Green Peace submission to the OSPAR Commission on Ocean Dumping of $\mathrm{CO}_{2}$ in the Norwegian Sea
\end{abstract}

\title{
GREENPEACE
}

OSPAR Commission, June 2002

Ocean Dumping of $\mathrm{CO}_{2}$ in the Norwegian Sea, Summer 2002

Submitted by Greenpeace International

\section{Introduction}

1.1 Over the last few years there has been increasing interest in the development of techniques for the sequestration and long-term "storage" of fossil fuel-derived carbon dioxide as a component of climate change mitigation strategies. Among the options under consideration are the disposal of liquified $\mathrm{CO}_{2}$ at sea, either at the seafloor (forming a "lake" of liquid $\mathrm{CO}_{2}$ ) or at intermediate depths in the water column (with the assumption that it will dissolve and become assimilated within the oceanic carbon reservoir).

1.2 Greenpeace International has for many years opposed plans for the disposal (or so-called "storage") of $\mathrm{CO}_{2}$ at sea, based on substantive environmental, legal and political concerns. In 1999, Greenpeace International published a detailed technical review of the options under discussion for ocean disposal and sequestration of $\mathrm{CO}_{2}$, concluding that such an approach, (quite apart from the enormous uncertainties and indeterminacies surrounding likely impacts and likely overall effectiveness of the proposal), was inherently unsustainable. The limited studies conducted into the fate of injected $\mathrm{CO}_{2}$ since that date have only served to illustrate the unpredictable behaviour of liquid $\mathrm{CO}_{2}$ released at depth ${ }^{15}$

1.3 The Greenpeace report also pointed out that the practice of ocean disposal (dumping) of $\mathrm{CO}_{2}$ would contravene the London Convention (1972), as well as more broadly the provisions of UNCLOS. Neither could it be used to offset emissions under the terms of the Kyoto Protocol to the UN Framework Convention on Climate Change (FCCC). Additionally, Greenpeace considers that pursuit of $\mathrm{CO}_{2}$ sequestration techniques is drawing vital resources away from the development and emplacement of renewable energy alternatives. Indeed, the possibility of such an option is being interpreted by many within industry as a "green light" for business as usual within the fossil fuel economy.

\footnotetext{
${ }^{15}$ Brewer, P.G., Friederich, G., Peltzer, E.T. \& Orr, F.M. Jr (1999) Direct experiments on the ocean disposal of fossil fuel $\mathrm{CO}_{2}$. Science 284, No. 5416: 943-945
} 
1.4 The Greenpeace International report ${ }^{16}$ on ocean disposal/sequestration of $\mathrm{CO}_{2}$ can be retrieved via the Internet at:

http://www.greenpeace.org/politics/co2/co2dump.pdf

\section{Ocean Dumping of $\mathrm{CO}_{2}$ in the Norwegian Sea}

2.1 Following the cancellation (due to substantial local and regional opposition) of proposed experimental releases of $\mathrm{CO}_{2}$ off the Kona Coast of Hawaii ${ }^{17}$, it has come to the attention of Greenpeace International that a similar experiment is now planned to take place off the coast of Norway, in the OSPAR region, during the summer of 2002.

2.2 According to the application submitted by the Norwegian Institute for Water Research (NIVA) to the Norwegian Pollution Control Authority (SFT) ${ }^{18}$, the planned experiment will involve the release of 5.4 tonnes of pure $\mathrm{CO}_{2}$ at the seafloor ( $800 \mathrm{~m}$ depth) at a location west of Storegga ( $75 \mathrm{n}$ miles NW of Kristiansund) in the Norwegian Sea between $22^{\text {nd }}$ July and $11^{\text {th }}$ August 2002. Although a relatively small release in terms of tonnage, the experiment is explicitly intended as a "proof of concept" study in support of future use of ocean disposal of $\mathrm{CO}_{2}$ generated as a waste from fossil fuel combustion as a climate change mitigation strategy. Moreover, the rationale of the study still relies on the highly questionable premise that the injected $\mathrm{CO}_{2}$ will remain isolated from the atmosphere "for 1000 years or more".

2.3 The study, proposed by NIVA on behalf of the Norwegian Research Council and a consortium of thirteen other institutes or organisations, will be funded by inter alia:-

- US Department of Energy (DOE),

- National Research Council (NRC), Canada,

- New Energy and Industrial Technology Development Organisation (NEDO), Japan \&

- Commonwealth Scientific and Industrial Research Organisation (CSIRO), Australia

2.4 Given the imminence of the planned releases, Greenpeace International wishes to bring this proposal to the attention of the OSPAR Commission. In addition to contravening the London Convention, to which all countries represented in the consortium are party, the dumping at sea of waste $\mathrm{CO}_{2}$ from fossil fuel combustion also contravenes Annex II to the OSPAR Convention (1992), given that $\mathrm{CO}_{2}$ could not be seen to fall under any of the five categories exempted from prohibition.

\footnotetext{
${ }^{16}$ Johnston, P., Santillo, D., Stringer, R., Parmentier, R; Hare, B; Krueger, M; (1999) Ocean disposal/sequestration of Carbon Dioxide from Fossil Fuel Production and Use: An overview of Rationale, Techniques and Implications. Greenpeace Research Laboratories Technical Note 01/99, Publ. Greenpeace International

${ }_{17}$ for details of the original proposals, see http://www.co2experiment.org/

${ }^{18}$ Application to SFT (Norwegian Pollution Control Authority) for permission to carry out an experimental release of $\mathrm{CO}_{2}$ (Carbon dioxide) in deep waters in the Norwegian Sea, Søknad om tester med $\mathrm{CO}_{2}$ I Noskehavet til SFT, 18/1, 2002
} 


\section{Action Requested}

3.1 Greenpeace International calls upon Contracting Parties to the OSPAR Convention to register their collective opposition to the proposed experimental releases of $\mathrm{CO}_{2}$ to the Norwegian Sea scheduled for July and August 2002, and to any future proposals of a similar nature within the Convention area.

3.2 In this context, Greenpeace International further requests Norway to refuse permission for NIVA and the associated research consortium to conduct the proposed Norwegian Sea experiment. 


\section{ANNEX III \\ DOCUMENT DESCRIPTION: GREEN PEACE PRESS RELEASE CLAIMING "NORWEGIAN APPROVAL OF OCEAN DUMPING THREATENS INTERNATIONAL LAW”}

\section{NORWEGIAN APPROVAL OF OCEAN DUMPING THREATENS INTERNATIONAL LAW}

July 9, 2002, Oslo: Greenpeace today called on the Norwegian Minister of the Environment to overturn approval given by the Norwegian Pollution Control Authority (SFT) for 5.4 tonnes of liquid carbon dioxide $\left(\mathrm{CO}_{2}\right)$ to be dumped at sea. The controversial experiment has already been rejected by Hawaii and opens the door to illegal ocean dumping of $\mathrm{CO}_{2}$.

The dumping of industrial waste at sea, including $\mathrm{CO}_{2}$ derived from fossil fuel use, is illegal under both the London Convention and the OSPAR Convention. If Norway approves this test it will be a first step towards allowing industrial dumping of $\mathrm{CO}_{2}$ at sea - which would break these international laws and encourage even further use of climate-changing fossil fuels.

"The sea is not a dumping ground. It's illegal to dump nuclear or toxic waste at sea, and it's illegal to dump $\mathrm{CO}_{2}$ - the fossil fuel industry's waste," said Truls Gulowsen, Greenpeace Norway climate campaigner.

$\mathrm{CO}_{2}$ is the world's biggest industrial waste product. Most comes from the burning of oil, coal and gas and it is the primary cause of climate change.

"Ocean dumping is not a solution to the problem of climate change. It will never be possible to guarantee that this waste will not return to the atmosphere, creating a climate time bomb for future generations," said Gulowsen. "The real solution to climate change is to replace fossil fuels with renewable energy such as solar and wind power."

A consortium of research institutions from Norway, Japan, Australia, the USA and Canada are proposing to undertake the first large scale $\mathrm{CO}_{2}$ ocean dumping experiment from late July to early August 2002, at 800 meters depth in the Norwegian Sea. The test has been funded from government bodies in these countries, as well as from ABB Corporate Research, and has support from the coal industry. It was rejected in Hawaii because of public protest.

"It's no surprise that the USA, Australia and Canada are supporting this project: These governments are now known as the Filthy Three for their blatent undermining of international agreements including climate change and the Earth Summit," said Gulowsen. "However, we are surprised that Norway once again is volunteering to be their tool in derailing international agreements and promoting continued use of fossil fuels".

Several other environmental organisations in Norway, including WWF and Friends of the Earth have also opposed the project. The Union of Concerned Scientists (a US based scientists-group) is opposed to ocean dumping of $\mathrm{CO}_{2}$ : According to the USC: "In light of the ecological risks of carbon sequestration in the deep oceans, and the unproven long-term benefits of this approach, UCS believes that further research of this approach should be abandoned."

Isaac Harp, a fisherman and the President of Hawaii's Coalition Against $\mathrm{CO}_{2}$ Dumping, a grass roots group that stopped two attempts to test the disposal of carbon dioxide $\mathrm{CO}_{2}$ in the ocean waters near 
Hawaii said: "In their attempts to justify continued use of fossil fuels, fossil fuel-supporters are seeking methods to $\mathrm{CO}_{2}$ in the world's oceans. This must be stopped, as there are so many other ways to combat climate change that are not nearly as insane as this approach."

Source: http://archive.greenpeace.org/earthsummit/news_july9.html 


\begin{abstract}
ANNEX IV
Document description: Green Peace press release denouncing experiment, calling members "boneheads"

July 15, 2002, Oslo A $\mathrm{CO}_{2}$ experiment that sounds more like bad science fiction than a global solution has been delayed because of international pressure. But the message is clear. Countries that are not yielding to pressure to reduce greenhouse gas emissions are quietly manoeuvring in the background to find hi-tech solutions rather than make the right move to green energy.
\end{abstract}

Any 5 year-old can tell you that if the kitchen sink is overflowing with water, you have to turn off the tap, not cut a hole in the floor and let it drain down to the basement.

But the scientists trying to solve the planet's problems are getting desperate and hell bent on finding a modern technological solution rather than stopping the problem at the source.

The same countries that are resisting international efforts to dramatically reduce carbon dioxide and climate change inducing emissions have cooked up a plan to dump this pollution in the ocean. A group of researcher institutions from the US, Norway, Canada, Australia and Japan are funding this mad science experiment to dump 5.4 tonnes of liquid carbon dioxide into the sea of Norway. But because of growing international opposition the experiment has been delayed.

These corporations, who know their technology belongs in last century, would rather keep lining their pockets while the atmosphere chokes than do what everyone knows will have to be done sooner rather than later. Old blokes, old money, old technology, old ideas - soon to be dead unless the earth's atmosphere loses out.

It didn't seem to occur to them that this technology is illegal in the first place.

Dumping industrial waste at sea, including $\mathrm{CO}_{2}$ from fossil fuel emissions is illegal under the international OSPAR and London Conventions.

Boneheads.

$\mathrm{CO}_{2}$ is the world's biggest industrial waste product and is causing more damage to our environment than any other single factor. Ice caps are melting, sea levels rising, coral reefs are being wiped out and our planet may never completely recover from the effects of climate change if we don't kick-start a revolution in clean green energy for all.

As governments scramble to find the least painful economic solutions to climate change, this consortium of countries was quietly working in the background without anyone knowing about it.

But over the last few weeks, the experiment has been the subject of concerns in Norway and around the world. The OSPAR commission also politely pointed out that they need to come up with a common position on this as soon as possible. 
Dumping blocks of frozen $\mathrm{CO}_{2}$ at sea and pumping liquid $\mathrm{CO}_{2}$ through pipelines under $3000 \mathrm{~m}$ which they expect would sink and form "lakes" on the sea bed - these are the rational solutions that have been suggested so that we can maintain an ignorant lifestyle of energy consumption.

\section{Boneheads.}

The delay of the Norwegian experiment is the first step. The Rainbow Warrior will arrive in Oslo, Norway on Tuesday and we will meet with the Norwegian Environment Ministry officals and others opposed to this plan

Source: http://www.greenpeace.org/news/details?news_id=22911 


\begin{abstract}
ANNEX V
Document description: Article from Planetark.org reporting on Greenpeace ship "Rainbow Warrior" protesting experiment.
\end{abstract}

\title{
Greenpeace ship heads to Oslo to fight $\mathrm{CO}_{2}$ dumping
}

17 July, 2002 OSLO - Greenpeace flagship Rainbow Warrior is heading for Oslo this week to stop a controversial experiment to dump 5.4 tonnes of liquid carbon dioxide $\left(\mathrm{CO}_{2}\right)$ in the sea off mid-Norway, a climate campaigner said.

Truls Gulowsen said Greenpeace was due to host a meeting onboard the ship on Wednesday between the Norwegian Environment Ministry, researchers and environment groups, aiming to stop the pilot project, designed to test disposing of $\mathrm{CO}_{2}$ in the ocean.

A consortium of research institutions from the United States, Norway, Canada, Australia and Japan, which fund the project, has decided to put the plan on hold while the ministry considers its environmental, political and legal impacts.

The project to test ocean dumping of $\mathrm{CO}_{2}$ - a climate gas known to damage the ozone layer - was originally scheduled to start this summer, to determine whether the method is feasible in reducing emissions to the atmosphere.

"This experiment threatens international law designed to stop the ocean being used as a dumping ground. It must never happen," Gulowsen told Reuters.

"We are very satisfied that the project is put on hold, but it is still important to spread the message that this is totally unacceptable," he said.

Greenpeace says $\mathrm{CO}_{2}$ dumping causes acidification as a result of the reaction with water, forming carbon acids. This in turn harms fish and other marine organisms in the sea and on the seabed.

A similar project has already been rejected by Hawaii due to public protest, Greenpeace said.

It said the dumping of industrial waste at sea, including $\mathrm{CO}_{2}$ derived from fossil fuel use, is illegal under the London Convention and the OSPAR Convention - both of which Norway is a member.

Source: Planet Ark http://www.planetark.org/avantgo/dailynewsstory.cfm?newsid=16901 


\begin{abstract}
ANNEX VI
Document description: Press release by Norweigan Environment Minister Børge Brende rescinding permit on August $22^{\text {nd }}, 2002$

\section{Release of $\mathrm{CO}_{2}$ in the Norwegian Sea May be in Conflict with International Environmental Conventions}
Environment Minister Børge Brende will not agree to an experimental project with release of $\mathrm{CO}_{2}$ in the Norwegian Sea at this time. - A possible future use of the sea as a storage place for $\mathrm{CO}_{2}$ is controversial. Such deposits may be in conflict with today's international rules related to protection of the marine environment, and the Ministry of the Environment must therefore turn down the application, says Environment Minister Børge Brende.

The Norwegian Institute for Water Research (NIVA) has applied for permission to release 5.4 tonnes of pure carbon dioxide $\left(\mathrm{CO}_{2}\right)$ in the Norwegian Sea, as part of research into ocean sequestration of $\mathrm{CO}_{2}$ as measures to combat climate change.

The Norwegian Pollution Control Authority (SFT) issued a permit on 5 July to NIVA to launch the experiment, with the justification that the release is limited in scope and cannot be expected to cause significant damage or harm. The decision was appealed by Greenpeace-Nordic and WWF-Norway. The Ministry of the Environment has chosen to accept the appeal, and has cancelled the permit given.

\title{
Must Be Discussed Internationally
}

In considering the appeal, the Ministry has emphasised that such releases of $\mathrm{CO}_{2}$ as would be studied by this research project have not been given thorough consideration in relevant international marine environmental conventions. In the opinion of the Ministry of the Environment the use of deep marine areas as possible future storage places for $\mathrm{CO}_{2}$ should first be thoroughly discussed internationally and the legal implications clarified.

The question as to whether the injection of $\mathrm{CO}_{2}$ is affected by the OSPAR Convention's dumping prohibition was introduced at the most recent Commission meeting under the Convention in June this year, against the background the proposed project in the Norwegian Sea. The meeting did not reach any final conclusions on this issue, but there is no doubt that the project is controversial and has been met with scepticism, both in relation to possible negative effects and because there is a reluctance to reopen the sea as a dumping place for waste. The legal working group under the Convention was asked by the meeting to undertake a detailed evaluation of different aspects related to possible release of $\mathrm{CO}_{2}$ in the seas. This evaluation is expected to be completed before the next meeting of the Commission which will take place in June 2003. The Ministry of the Environment will under no circumstances open up for $\mathrm{CO}_{2}$ release in the sea until this evaluation has been completed.

Ocean sequestration of $\mathrm{CO}_{2}$ as a possible future measure to combat climate change has only been given very limited consideration under the Climate Change Convention. In the coming discussion on this issue, the possibilities of leakages to the atmosphere will be a central topic. The Ministry of the Environment states in its decision that an international discussion of the issue is desirable and necessary, and has also based its decision on the fact that the experiment will not significantly increase understanding of possibilities for future leakages of $\mathrm{CO}_{2}$ to the atmosphere.

Source: http://odin.dep.no/md/engelsk/aktuelt/pressem/022051-070061/index-dok000-b-n-a.html 


\begin{abstract}
ANNEX VII
Document description: Article from Nature reporting on project's halt. September $5^{\text {th }} 2002$

Norway sinks ocean carbon study

JIM GILES
\end{abstract}

[LONDON] Pressure from environmental groups looks set to scupper an international research team's attempt to test the feasibility of sequestrating large volumes of carbon dioxide in the ocean.

The Norwegian government has intervened to block the proposed release of 5 tonnes of liquefied $\mathrm{CO}_{2}$ off its coast. Three months ago, the researchers' plan to carry out the same experiment on a larger scale near Hawaii was abandoned in the face of environmental objections (see Nature 417, 888; 2002).

Now the team - which includes engineers, oceanographers and ecologists from the United States, Norway, Japan and Canada — is running out of options and may have to abandon the idea altogether. That would be a major blow to global efforts to pursue oceanic carbon sequestration as a possible response to global warming — and a big victory for green groups, some of whom regard sequestration as a diversion from the need to cut $\mathrm{CO}_{2}$ emissions.

The scientists had planned to release the $\mathrm{CO}_{2}$ at a depth of 800 metres, and monitor its impact on the Norwegian Sea, to investigate whether the ocean could absorb much larger volumes of $\mathrm{CO}_{2}$ from power plants, for example.

A permit for the experiment was granted by the Norwegian Pollution Control Authority on 5 July. But Børge Brende, the Conservative Party environment minister in Norway's coalition government, decided to review the authority's decision after protests from Greenpeace and the World Wide Fund for Nature. The ministry announced on 22 August that the project would not go ahead.

"We think it should be researched and a decision made on the science," complains one of the researchers, Eric Adams, a hydrodynamicist at the Massachusetts Institute of Technology. "This is politics meddling with science," he says.

The pressure groups argued that the experiment would contravene ocean-pollution treaties. They also object to any large-scale release of $\mathrm{CO}_{2}$ into the oceans, claiming that it could damage marine ecosystems and would eventually leak back to the atmosphere. Researchers counter that the experiment was designed precisely to investigate whether such fears are justified.

The team is considering what to do next. Adams says they could do the work quite legally in international waters, although most are too deep for this study. The second delay has also complicated matters with the project's funders, as the original time-frame for the experiment has now expired.

Source: http://pubs.acs.org/subscribe/journals/esthag-a/36/i21/pdf/1102news 1.pdf\#1 


\begin{abstract}
ANNEX VIII
Document description: Letter from experiment collaborators to Environmental Science and Technology, complaining of political interference in the experiment. November 1, 2002

\section{International Field Experiment on Ocean Carbon Sequestration}

Under pressure from Greenpeace Nordic and World Wildlife Fund-Norway, Norwegian Minister of Environment Børge Brende recently reversed the decision of the Norwegian Pollution Authority (SFT) and rescinded our permit to conduct a small-scale study of ocean carbon sequestration (see story on p. 401A). The permit originally was granted by SFT in full accordance with Norwegian laws and regulations. As members of the scientific team for this experiment, we are angered by the intervention of politics into basic science. We feel this sets a bad precedent, not just for our research area, but for all scientific endeavors.
\end{abstract}

Our project involved researchers from 15 institutions from 5 countries in a collaborative study of the physical, chemical, and biological changes associated with direct injection of $\mathrm{CO}_{2}$ into the ocean. The objective of our work was to better understand the possibility and environmental impacts of using ocean carbon sequestration to mitigate global climate change. This is directly in line with the United Nations Framework Convention on Climate Change, which explicitly mentions the need for using sinks and reservoirs as one component of a more comprehensive portfolio of strategies for reducing greenhouse gas emissions.

An array of instrumentation, including two remotely operated vehicles, would have monitored the fate of liquid $\mathrm{CO}_{2}$ discharged in the Norwegian Sea at a depth of 800 meters. Over one week, a total of about 5 tons would have been released, about half the annual "emissions" from an average Norwegian. The $\mathrm{CO}_{2}$ would have exited as small buoyant droplets, forming a plume and dissolving within a distance of about 100 meters.

Everyone concerned concedes that our experiment, alone, would have had no significant environmental impact. The minister says that more science is needed before full-scale implementation of ocean sequestration (involving upwards of $10^{9}$ tons of $\mathrm{CO}_{2}$ ) can be considered prudent. But he also argues that full-scale implementation is controversial and requires more international debate. That is exactly why we wanted to conduct this experiment - to improve our basic understanding so that we can have an informed debate.

All of us recognize we must eventually dramatically reduce our reliance on fossil fuels, which account for over $85 \%$ of worldwide commercial energy consumption. However, analyses show that promoting conservation, energy efficiency, fuel substitution, and alternative energy sources probably will not be able to reduce greenhouse gas emissions fast enough to avoid significant climate change. Therefore, we feel it is imperative to be able to explore as many potential mitigation options as possible. On the basis of research results, informed political decisions can then be made as to what options are desirable. Eliminating options at an early stage is a decision we may regret. Ocean carbon sequestration has to be considered, in part, because it is the biggest mitigation option functioning today. Through the natural carbon cycle, the ocean annually 
sequesters about $7 \times 10^{9}$ tons of industrial $\mathrm{CO}_{2}$, which is about one-third of the world's emissions.

As researchers, we have an open mind as to what role, if any, additional ocean sequestration should play. However, we believe the decision should be made with the benefit of the best scientific understanding. We also believe such decisions should be made in the open. Having a single minister (of the third largest oil-exporting country, no less) overturn the open process of a permitting agency under political pressure from special interest groups is very unfortunate.

\section{ERIC ADAMS}

Massachusetts Institute of Technology, USA

MAKOTO AKAI

National Institute of Advanced Industrial Science and Technology, Japan

GUTTORM ALENDAL

Nansen Environmental and Remote Sensing Center, Norway

LARS GOLMEN

Norwegian Institute for Water Research, Norway

PETER HAUGAN

University of Bergen, Norway

HOWARD HERZOG

Massachusetts Institute of Technology, USA

STEPHEN MASUTANI

University of Hawaii, USA

SHIGEO MURAI

Research Institute for Innovative Technology for the Earth, Japan

GERARD NIHOUS

Pacific International Center for High Technology Research, USA

TAKASHI OHSUMI

Research Institute for Innovative Technology for the Earth, Japan

YOSHIHISA SHIRAYAMA

Kyoto University, Japan

CRAIG SMITH

University of Hawaii, USA

ERIC VETTER

Hawaii Pacific University, USA

C. S. WONG

Institute of Ocean Sciences, Canada

Source: http://pubs.acs.org/subscribe/journals/esthag-a/36/i21/pdf/1102letters.pdf 


\begin{abstract}
ANNEX IX
Document description: Article from Environmental Science and Technology, reporting on project's halt. November 1, 2002
\end{abstract}

\title{
Sequestration Experiment is Drowning
}

Plans to run large-scale trials of ocean sequestration of carbon dioxide (CO2) are being hampered by growing opposition. In August, the Norwegian environment minister refused permission for an experiment in the Norwegian Sea, and in June, local opposition foiled attempts to secure permits in Hawaii. The international scientific team that is planning the sequestration experiment says that it is still hopeful of finding a suitable test site.

In 1997 at Kyoto, Norway, the United States, Australia, Japan, and Canada signed an agreement under the OECD's Climate Technology Initiative to undertake ocean sequestration trials. Nevertheless, environment minister Børge Brende cancelled a permit issued by the Norwegian Pollution Control Agency to conduct the experiment after environmental groups appealed. Instead, he said that ocean sequestration should first be "discussed internationally and the legal implications clarified". In particular, Brende is concerned that the project could conflict with the 1992 OSPAR Convention, formerly the Oslo and Paris Conventions, which sets out to protect the marine environment of the northeast Atlantic Ocean. He is awaiting an evaluation by the OSPAR Commission's legal group, scheduled for their next meeting in June 2003.

"We are very disappointed about this denial to conduct fundamental research on climate mitigation technologies, but we will find somewhere to do our experiments," says Lars Golmen, who is the project manager for the consortium in Norway. Eleven researchers from the project have signed a letter protesting Norway's decision (p. 399A). The research consortium, which includes teams from Norway, the United States, Australia, Japan, and Canada, has only one year's funding left.

Meanwhile, environmental organizations are relieved. "We regard the project as dead in Norway," says Truls Gulowsen of Greenpeace, adding that injecting $\mathrm{CO}_{2}$ into the seas is an unsustainable way of solving the climate problem. Greenpeace also cites concerns about the effects on marine life and whether oceans can store large amounts of CO 2 for long periods.

The project involved injecting 5.4 metric tons of liquid CO 2800 meters below sea level and then studying the behavior of the dispersing plume and its impacts on marine life. - MARIA BURKE

Source: ENVIRONMENTAL SCIENCE \& TECHNOLOGY / NOVEMBER 1, 2002 http://pubs.acs.org/subscribe/journals/esthag-a/36/i21/pdf/1102news1.pdf\#1 


\begin{abstract}
ANNEX X
Document description: Article from Environmental News Service reporting on project's halt OSLO, Norway, August 26, 2002 (ENS) - A last minute veto from Norway's environment minister has scuppered what would have been the world's first attempt to demonstrate sequestration of carbon in the oceans by injecting liquid carbon dioxide $\left(\mathrm{CO}_{2}\right)$ into the Norwegian Sea. Carbon sequestration is being considered as a technique to remove the main greenhouse gas, $\mathrm{CO}_{2}$, from the atmosphere to curb global warming.

Echoing the arguments of environmental nongovernmental organizations that had campaigned to stop the experiment, Børge Brende said in a statement that the project "could come into conflict with current international regulations on the marine environment."
\end{abstract}

\title{
Norwegian Environment Minister Børge Brende (Photo courtesy Office of the Minister) A license for the experiment granted by the Norwegian pollution control agency on July 5 was therefore rescinded.
}

"In the opinion of the environment ministry, the use of deep sea marine areas as potential storage places for $\mathrm{CO}_{2}$ must first be thoroughly discussed at international level and clarified legally," Brende said.

Led by the Norwegian Institute for Water Research (Niva), a coalition including American, Japanese, Canadian and Australian organizations had planned to inject five metric tonnes of liquid $\mathrm{CO}_{2}$ at 800 metres depth off the coast of Norway.

The $\mathrm{CO}_{2}$ ocean sequestration project was originally set up to run a similar test off Hawaii, but this plan was dropped in the face of local opposition.

The decision has prompted Niva to decide to drop out of the project, a spokesperson told reporters today.

Capturing and sequestering $\mathrm{CO}_{2}$ from fossil fuel burning is being pursued as a possible means of reducing greenhouse gas emissions. Last year, the European climate change program concluded that it offered "good potential" for reducing emissions, but that further research is needed, in particular to reduce costs.

\section{Svalbard, Norway north of the Norwegian Sea (Photo courtesy NOAA)}

The Norwegian oil firm Statoil is already injecting some one million metric tonnes of $\mathrm{CO}_{2}$ per year into the rock strata of an offshore oilfield in the North Sea, but no one has yet tried sequestration in the oceans.

Environmental groups argue that the project would have meant "dumping" $\mathrm{CO}_{2}$ in the ocean in violation of the 1972 London dumping convention and of the 1992 Ospar convention on protection of the North Sea environment. The Ospar Commission discussed this issue in late June but is unlikely to have an answer until next year, a spokesperson said.

Greenpeace and other NGOs also claim that injecting $\mathrm{CO}_{2}$ into the oceans could harm wildlife, and that the gas might return much more quickly than expected to the atmosphere, undoing the object of the exercise.

The NGOs fear that sequestration of $\mathrm{CO}_{2}$ might prop up the fossil fuel industries and distract attention from efforts to move towards a low carbon economy based on renewable energy such as solar and wind. 
Still, Norway is making an effort to limit the emission of greenhouse gases. On May 30, Norway became one of the first industrialized countries to ratify the Kyoto Protocol on reductions in emissions of greenhouse gases.

"Global climate change is the largest environmental threat to our planet in this century. By being one of the first industrialized countries to ratify the Kyoto Protocol, we signal the seriousness we attach to this problem and that we want to do our share to solve it."

The Kyoto Protocol to the UN Framework Convention on Climate Change establishes legally binding commitments on limitations and reductions in emissions of six greenhouse gases, including $\mathrm{CO}_{2}$. The protocol was adopted in 1997 and commits Norway to limit its emissions of greenhouse gases in the period 2008 to 2012 to a maximum of one percent above its emissions level in 1990.

Source: Environmental News Service http://ens-news.com/ens/aug2002/2002-08-26-02.asp 